\title{
THE WORLDVIEW OF THE CHARACTERS AND UPDATING OF METAPHORS IN THE TEXT
}

\section{Ulugova Shohida Shokhrukhovna}

Samarkand state institute of foreign languages, Samarkand, Uzbekistan

firuzahalimova@mail.ru

\section{ABSTRACT}

This article examines the use of metaphors in the text of works of art. In particular, based on the material of the novel by Charlotte Bronte "Jane Eyre", using conceptual metaphors that reflect the mental state of a person, the inner world, worldview, and attitude to life of the main characters of the work, such as Jane, Rochester and John, are revealed, and the similarities and differences of their character are shown.

In the article, the main position is taken by the question of the degree of representation of persons-conceptualizers who perceive the world picture in metaphors. This makes it possible to study the problem and collect information about the characters in the work, including the cognitive activity of Jane Eyre.

Ultimately, the analysis of metaphor, actualized in the speech of the main characters of the novel, it became apparent that these expressions, along with a reflection of the attitude to life characters, give impetus to the formation of metaphors. In particular, the expansion of the semantic scope of metaphorical expressions used by Jane is a product of the development of her cognitive abilities and capabilities based on increasing life experience.

Keywords:

Conceptual metaphor, ideology, conceptualization, interpretation of the text

Article Received: 18 October 2020, Revised: 3 November 2020, Accepted: 24 December 2020

Since ancient times, man has sought to know the surrounding reality and comprehend "his own world". The metaphorical appearance of the world is a means of realizing such aspirations. Humanity is always on the path to ordering, systematizing and classifying the picture of the world, and translating it into reality, as far as it is necessary for practical needs. A person who has felt the possibility of generalizing knowledge in various spheres of metaphor, and at the same time the emergence of relationships even in such distant spheres - natural reality and the spiritual world, human life and the Universe-undoubtedly has an interest in the process of metaphorization.

The tradition of interpreting metaphors more as embellishments of artistic expression, speech transference, and stylistic means began in ancient times. The followers of Aristotle understand the concept of "metaphor" (Greek. "change", "the transfer of") as "replacing one word with another". Such an interpretation of this phenomenon occupies an important place in dictionaries. Compare: "metaphor is one of the most common types of meaning transference, a type of transference based on the similarity between events and phenomena. Being a hidden comparison, a metaphor expresses the meaning of the thing being compared, without mentioning it, through the thing with which it is compared (that is, the word expressing it)" [8. 170]. In dictionaries in English, metaphor is described as a way of decorating speech [9. 137].

It is known that the comparative approach to the analysis of metaphor has long maintained its dominance without any changes. We should not forget that the first "sprouts" of metaphor as a multidimensional phenomenon began to appear in the time of Aristotle and Plato. Unfortunately, the decline that engulfed the subject of rhetoric in the following centuries also led to the stagnation of the theory of metaphor. In addition, the metaphor was viewed as a toy, a joy, and interpreted it not as one of the main forms of language, but as an additional mechanism [5. 45].

In subsequent studies, special importance was attached to the role of metaphor in the formation of a linguistic picture of the world, and 
it received the status of a means of thinking about the world. It is known that there is a conceptual system of a person that forms activities aimed at the formation of personal meaning [4. 91]. This means that the principle of conceptualization of the acquired knowledge occupies a significant position in the actualization of the epistemological problem. Accordingly, the metaphor remains a stylistic trope, and is given the status of a model of reality, revealed in the process of human thinking [4. 108].

The essence of the tasks performed by the metaphor began to change only by the 60 s of the twentieth century. Because during this period, new approaches began to appear in the scientific study of metaphor. The American logician M. Black, who introduced the terms "focus" and "frame" into the theory of metaphor, was one of the first to study the phenomenon of metaphor in direct connection with the theory of scientific knowledge. M. Black, partly using the conclusions of A. Richards, developed a method of analysis with the approach of interaction (interaction) "interaction approach". Within the framework of this approach, it was proved that the metaphor shows its activity not at the level of a combination of words, but at the internal level, located more deeply. In addition, the author believes that the metaphor appears as a result of the relationship of the conceptual structures underlying the dictionary units [2. 153-172].

As an example, M. Black analyzed the sentence "The chairman plowed through the discussion", and noted that only one word, i.e. "plow" is used in a metaphorical sense, and the rest-in a direct meaning. According to the scientist, it is the plowed form that is the center of the metaphor (focus), and the other words make up its frame.

Similarity on the basis of metaphorical transfers was reflected in the definition of Aristotle, a metaphor is a name transferred on the basis of similarity from genus to species, or from species to genus, or from species to species [1. 669]. This definition of the Greek philosopher is supported by most scientists. Some prefer to use the definition of a metaphor as a "shortened comparison" (Potebnya), others (for example, the Polish scientist (Y. Kasyan) - to warn about the existence of a two-way relationship between a metaphor and a comparison: if you check the origin, then, of course, you can find out that this or that metaphor develops from a certain similarity. However, on this basis, we can also draw the opposite conclusion - many comparisons have come from metaphors [7. 41].

According to N. Makhmudov's interpretation, the analogy is based on the similarity of properties, features or relations of different objects, and, according to this similarity, information about one object is transferred to another object. This means that this cognitive process is undoubtedly the essence of the metaphor phenomenon [6. 8].

M. Black is convinced that the interactive approach to the essence of the phenomenon of metaphor, devoid of obvious shortcomings of the previous, i.e., the substitutional and comparative approaches, makes it possible to understand the true essence of the phenomenon of metaphor and the principles of actualization. M. Black notes that the interactive approach is based on the following concepts [2. 167-68]:

1. The metaphorical opinion has two subjects - one of them is the main one, and the second is the auxiliary one.

2. These entities should be considered as systems.

3. The mechanism of the metaphor consists in adding to the main subject associations associated with the auxiliary subject.

4. These additions usually form associations that are present in the mind of the speaker, however, they can sometimes occur in emergency cases.

5. In the metaphor, there are cases of implicit transfer of the opinion about the main subject to the auxiliary subject.

6. The above-mentioned case leads to the transfer of the meaning of words in the system to which the metaphorical expression refers. Some of 
these hyphenations acquire a metaphorical connotation (however, the expressive effect of the secondary metaphors that have arisen in this way will be weaker).

7. In general, there are no rules that control the transfer of such a value. It is always very difficult to comment on why it is not necessary to move from the stage of transferring the meaning of individual metaphors to the formation of other metaphors.

At the same time, it should be recalled that other scientists also claimed the presence of two thoughts in a metaphorical expression. A. Richards also used the words tenor ("meaning") and vehicle ("shell, image") to express "two thoughts acting together" [5. 48]. However, relying on "double thinking" can make it difficult to determine the nature of a metaphorical phenomenon. If you apply only the seven listed concepts, then other aspects of this phenomenon may be left out.

Thus, the main idea of the conceptual theory is to prove the role of metaphors in thinking, in understanding new concepts. Metaphor, used as a linguistic phenomenon and rhetorical means, is a secondary semantic formation in relation to the product of thinking. Simply put: first the cognitive metaphor, and then the language metaphor.

In the article, the main position is taken by the question of the degree of representation of persons-conceptualizers who perceive the picture of the world in metaphors. This makes it possible to study the problem and collect information about the characters of the work of Sh. Bronte's "Jane Eyre", including the cognitive activity of Jane Eyre.

It is clearly seen that the speech of the main characters of the work of Jane Eyre, Rochester and St. John is replete with metaphors. At the heart of these metaphorical structures, which at first glance seem far from each other, are interrelated conceptual metaphors that reflect the worldview of the characters based on certain values. For this reason, a comparative analysis of linguistic and conceptual metaphors can reveal the main idea of the novel "Jane Eyre", as well as provide an opportunity to observe the stages of psychological, emotional, moral, intellectual development of Jane Eyre, the main character of this feminist work.

It is known that the characters with peculiar qualities, such as Jane Eyre, Rochester and the priest John, occupy a leading place in the creation of the ideological theme of the novel. In particular, the life of Jane, orphaned in early childhood, proceeds in a struggle, the girl is forced to constantly defend herself. Educated Jane goes to work at Thornfield as a teacher. She likes a stormy life, but at the same time she is modest and well-mannered. Rochester, "burned" on his first marriage, seems cold and mocking, but at heart he is cordial and sincere. The priest John, a member of the clergy, likes Jane, but he turns out to be her cousin. He is strict, stubborn, sensitive, is a supporter of prudent actions with a manifestation of firmness of spirit, always ready to help the poor.

Jane's attitude to life is mainly reflected in the structures formed on the basis of the conceptual metaphor "Life is a Journey", which change structurally throughout the novel. Jane is constantly expanding the boundaries and changing the forms of the concept of journey - "journey" as part of a conceptual metaphor:

Jane goes to Thornfield to work as a governess. Her eight years in Lowood had completely cut her off from the world around her. Now she wants to "take a deep breath", but at the same time she does not have a full understanding of the future prospects. This distrust of the future is reflected in the conceptual metaphor "Life is a Journey". More precisely, words and expressions such as cut a drift" go with the flow", "port" indicate a path, a journey to the sea. From the thoughts of a person caught in the current, the direction and purpose disappear, he freely floats with the current. In any case, soon the feeling of freedom is replaced by the fear of getting lost on the way. Communication with the outside world is lost, and the hope of achieving the goal is reduced. 
However, the journey has already begun, and there is no turning back.

Thus, here the semantic source is the concept of "journey", which reaches the concept of "life" and is compared with it.

According to Jane, life is akin to a sea voyage, which takes place alone, surrounded by distrust. However, she has already made a decision to leave Lowood, see another world and meet people, and returning back is no longer possible.

Obviously, here the conceptual metaphor fully demonstrates Jane's views on life. Because of her youth and inexperience, she imagines life as lonely and purposeless. The same meaning is expressed in another metaphor: Alas, this isolation- this banishment from my kind! Not only the anchor of hope, but the footing of fortitude was gone [10.321].

Arriving at Thornfield, Jane is met by the housekeeper, Mrs. Fairfax, and the future pupil of the new governess, the Frenchwoman Adele. Jane describes her work as: I was now at last in safe heaven [10. 90]. This expression is also based on the conceptual metaphor "Life is a Journey". However, a carefree and easy life does not satisfy Jane:

To spend the long winter evening with her, and her only, was to quell wholly the faint excitement wakened by my walk,-to slip again over my faculties the viewless fetters of an uniform and too still existence; of an existence whose very privileges of security and ease I was becoming incapable of appreciating. What good it would have done me at that time to have been tossed in the storms of an uncertain struggling life, and to have been taught by rough and bitter experience to long for the calm amidst which I now repined! [10. 108].

In this fragment, the above-mentioned conceptual metaphor, which includes a sea voyage, is again updated. The metaphor frame is expanded by adding the details "small boat", adverse weather conditions (tossed, storm). Jane, tired of Thornfield's easy life and calm, interprets this life as a fetter that binds her legs. At the same time, she does not forget that you need to appreciate this peace. Since being in a fickle environment, encountering a boat with a storm while traveling on the sea (Jane presents herself as such), and finding ways to get rid of troubles are also not very pleasant.

The month of courtship is over, and soon Jane will be Rochester's wife. In the absence of Rochester, who has gone to visit small farms, Jane is worried and worried about the expected changes in life. She walks in the garden, dreaming of Rochester. Jane, who compares her life to that of Rochester, likens the path of life to a river. At the same time, the directions of metaphorical thinking take the following form:

1. Depth of sea to which the brook runs $\rightarrow$ the depth of Rochester's life;

2. Shallows of strait channel $\rightarrow$ the shallowness of Jane's life;

3. Expansive and stirring $\rightarrow$ rich life experience, exciting life experience.

If the conceptual basis of the metaphor compares the life of Rochester with a small mountain river rushing to the sea, then Jane's life is compared with the shallows in the course of the channel. This quality shows a metaphorical contradiction: on the one hand, Jane's deep respect and passion for Rochester is shown, and on the other hand, her modesty. Such a metaphor indicates the inevitability of reflection.

However, the achievement of desires does not always proceed smoothly. After learning that Rochester has another wife, a mad woman, whom he keeps in a third-floor attic, Jane leaves Thornfield. Stranded in the nearby Witcross region, with no means of support, and feeling hungry and tired, Jane does not fall into despair. On the contrary, she believes in God and expects salvation from him.

Rochester's metaphorical mental activity reflects a tough, harsh life. In his youth, he fell in love with Bertha Mason, married her, and this becomes the cause of dissatisfaction with the life of Rochester. As a result, he got used to treat others coldly, mockingly, and complain about the 
unfairness of life and fate. Such a life, no doubt, no one will like it. Mental trauma affects a person's mood, activity, worldview, and how they position themselves. An example of this is the content of the metaphors that define Rochester's attitude to life:

I started, or rather (for like other defaulters, I like to lay half the blame on ill fortune and adverse circumstances) was thrust on to a wrong tack at the age of one-and-twenty, and have never recovered the right course since... [10. 126].

These lines are taken from a conversation between Rochester and Jane. Rochester, in response to Jane's irony, admits that there are no flaws in her character. In his response, Rochester, commenting on his life experience, emphasizes that the path of life does not depend on the choice of a person, it is predetermined by God (ill fortune). It is known that the life path consisting of the triad "source-direction-goal" leads to good results. To achieve the goal, you need to choose the right direction. So Rochester's metaphor of "life is a journey forced on a wrong track" has the meaning of "the journey that led life on the wrong path".

Rochester can be attributed to the tragic characters. His first marriage was a tragedy. The work does not provide the reader with detailed information about his previous life, however, from a conversation with Jane, you can understand how depressing his perception of life is. This attitude to life and worldview is manifested in the following metaphorical expressions:

a) Rochester's memories of a shameful relationship with the French dancer Celine:

I had not, it seems, the originality to chalk out a new road to shame and destruction, but trod the old track with stupid exactness not to deviate an inch from the beaten centre [10.132].

In these lines, he again likens his life to a journey in this direction. This path had already led him to Bertha Mason, but it had ended in disgrace and discontent.

b) Rochester's confession that caused Jane to leave:
Divine justice pursued its course; disasters came thick on me: I was forced to pass through the valley of the shadow of death. His chastisements are mighty; and one smote me which has humbled me forever [10. 430].

In the situation described, life without Jane is compared to the subsequent disaster. This, in turn, with the help of an allusion, implies punishment for what was done. In an attempt to save his crazy wife, who had set fire to the house, he was badly injured.

There is no doubt that at the heart of all these metaphors is the conceptual metaphor "Life is a Journey". As mentioned earlier, the journey has a starting, middle, and ending point. Some directions are correct, others are incorrect.

Rochester has become the "prey" of the metaphor, his life is completely controlled by fate. For this reason, he emphasizes the dangers and obstacles on the path of life, as if in one of the metaphors he uses. All this indicates a depressive mood, a desperate worldview of Rochester.

To live, for me, Jane, is to stand on a cratercrust which may crack and spew fire any day [10. 205].

In this speech structure, a peculiar metaphor of attitude to life is actualized: the source of the metaphor from Jane's answer is the crater-crust. The reason for the appearance of such a source is that Bertha set fire to her room a few days ago. The lexeme "crater" (crater) has the dictionary meaning "spherical hole of a volcano", while crust means "the remains of ash after the eruption of a volcano". So, the content of the above metaphor is related to a fire that occurred one day earlier, since the word "crater" is associated with a sparkling rock, fire, smoke. As a result, this metaphor reminds us of hell. In addition, the reference to the concept of "crater" leads us to the idea of a dragon, depicted in the folklore of many peoples as "a terrible animal that spews fire". In Rochester's mind, his wife is associated with such creatures, and being near such a volcano is a constant threat to the spouse.

Rochester continues to describe his longsuffering life: 
Well then, Jane, call to aid your fancy: suppose you were no longer a girl well reared and disciplined, but a wild boy indulged from childhood upwards; imagine yourself in a remote foreign land; conceive that you there commit a capital error, no matter of what nature or from what motives, but one whose consequences must follow you through life and taint all your existence. Mind, I don't say a crime; I am not speaking of shedding of blood or any other guilty act, which might make the perpetrator amenable to the law: my word is error. The results of what you have done become in time to you utterly insupportable; you take measures to obtain relief: unusual measures, but neither unlawful nor culpable. Still you are miserable; for hope has quitted you on the very confines of life: your sun at noon darkens in an eclipse, which you feel will not leave it till the time of setting... [10. 206].

In the above fragment, Rochester tells Jane about his troubles in his youth. Of course, it is difficult to reveal the secrets stored in the soul. Therefore, by using metaphor as a way of stylistic expression, the character tries to recreate his difficult past. The conceptual metaphor of "A Life is a Day" is involved here. Everyone knows that noon is the lightest and hottest time of the day, while night is the coldest and darkest time, and sunset indicates the beginning of the night. In the content of the metaphor "A Life Time is a Day" Rochester also includes the concept of "twilight", as the day ends after dusk. The changing times of day are compared with the life stages. So, in this case, metaphorical conceptualization consists of the following stages: The

Sun $\rightarrow$ Source of light and freedom;

Night $\rightarrow$ the highest point of life;

Sunset $\rightarrow$ death;

Darkness $\rightarrow$ trauma that prevents the feeling of freedom.

Rochester's depressive attitude to life is verbalized through this metaphor, the wound inflicted on his heart in his youth haunting him throughout his life. As a result, he distances himself from the bright pages of life. This metaphor not only reflects his attitude to life, but also affects his thoughts and actions.

Thoughts about the life of the priest John are connected with his activities, his spiritual rank. This ambitious and arrogant man, setting out as a missionary, chose Jane as his wife. After receiving a rejection from Jane, St. John Rivers is very upset, and, upon arrival in India, remains there for the rest of his days. For this reason, his attitude to life is different from that of Jane and Rochester.

The priest has a different idea of life. Its metaphorical expression can be represented by the metaphor "Life is a Journey with Obstacles". Unlike Rochester, he believes in God, and believes that any difficulty can be overcome with God's help. In his life scenario, there are obstacles that every person has to face, including people who have set foot on the path of life without their desire, are doomed to go through it to the end, and this irritates them. What should I do? According to the priest, one should not fall into despair, but look for the right path and believe that, by the will of fate, this path will be smooth and lead to the goal.

According to the interpretation of cognitive scientists, a metaphor that has arisen in extreme circumstances has a hidden power that shapes and reflects our experience. Such a metaphorical choice has a rapid impact on the mind of the listener (reader). In the metaphor used by John Rivers, there is just such a subtext, his peculiar attitude to life. Since life is a difficult path, but if a person is strong, purposeful and acts systematically, then, undoubtedly, he will pass this path with dignity and achieve his goals. This is the opinion implied in his conclusion:

It is just what I want. And there are obstacles in the way: they must be hewn down [10. 392].

In the following narrative structure, we can also observe the statement "life is a long journey":

I am the servant of an infallible Master. I am not going out under human guidance, subject to the defective laws and erring control of my feeble fellow-worms: my king, my lawgiver, my 
captain, is the All-perfect. It seems strange to me that all round me do not burn to enlist under the same banner,-to join in the same enterprise. All have not your powers, and it would be folly for the feeble to wish to march with the strong [10.386].

The pride of leaving on a missionary journey to India is expressed in such phrases as "infallible Master", "not...human guidance, defective laws and erring control... feeble fellowworms". The priest likens his future missionary life to a great activity under the patronage of the
Creator, using the high-style language units "banner", "join in", "march". All of these units are aimed at encouraging Jane to leave with him.

Thus, in the metaphors found in the speech of the main characters of the work, their attitude to life is expressed, but these relations are not the same. These differences have different semantic connotations. The total number of metaphors that reflect the attitude to life in the novel is 36 . Their distribution by content can be seen in the following

Metaphors that reflect the attitude to life in the speech of the characters of the novel

\begin{tabular}{|l|c|c|c|}
\hline \multicolumn{1}{|c|}{$\begin{array}{c}\text { Metaphors of attitude to life } \\
\text { (total number -36) }\end{array}$} & $\begin{array}{c}\text { Jane Eyre } \\
\text { (14) }\end{array}$ & $\begin{array}{c}\text { Edward } \\
\text { Rochester } \\
\text { (12) }\end{array}$ & $\begin{array}{c}\text { St. John } \\
\text { Rivers } \\
\text { (10) }\end{array}$ \\
\hline $\begin{array}{l}\text { Journey "path, journey" (without goal and } \\
\text { control) }\end{array}$ & 8 & 2 & 0 \\
\hline Journey "the way, the journey" (dangerous) & 0 & 2 & 0 \\
\hline Journey "path, journey" (forward or backward) & 2 & 0 & 1 \\
\hline $\begin{array}{l}\text { Journey "path, journey" (in the right or wrong } \\
\text { direction) }\end{array}$ & 0 & 3 & 0 \\
\hline $\begin{array}{l}\text { Journey "the way, the journey" (with } \\
\text { difficulties) }\end{array}$ & 0 & 1 & 4 \\
\hline Journey "the way, the journey" (aimless) & 0 & 0 & 5 \\
\hline Journey "the way, the journey" (fight) & 1 & 1 & 0 \\
\hline Journey "the way, the journey" (pursuit) & 1 & 2 & 0 \\
\hline Life is a book "life is a book" & 1 & 0 & 0 \\
\hline Life is a river "life is a river" & 1 & 0 & 0 \\
\hline Life is a day "life is a day" & 0 & 1 & 0 \\
\hline
\end{tabular}

It is clear from the table that in the metaphors of the attitude to life in Jane's speech, metaphors with the content "life is an aimless and uncontrolled journey" are most often found. However, most of these metaphors are verbalized in the first part of the novel, that is, when depicting Jane's sorrowful life in an orphanage.

The metaphors of the attitude to life in Rochester's speech are divided into three types: a) "life is an aimless journey"; b) "life is a journey in the wrong direction"; c) "life is a pursuit". Priest John describes his life as "an aimless journey" and "a life path littered with complexities".

The metaphors about Jane's life are set out in more detail than those of other characters, they figuratively reflect various aspects, stages of life. This, first of all, indicates the desire of the narrator, talking about life (Jane), to get to the heart of his emotional experiences, and his greater seriousness in relation to the rest. Secondly, it hints at the speaker's optimism. The metaphors used after Jane grows up have a variety of forms, which indicates an increase in Jane's life experience. Now she prefers metaphors in the form of tossed in the storms of an uncertain struggling life [10. 108].

... felt as a wanderer on the face of the earth [10. 216]. 
I felt degraded. I doubted I had taken a step which sank instead of raising me in the scale of social existence [10. 344].

Metaphors about Rochester's life are also based on his experience, but these metaphorical structures express the speaker's depressive state, the limited possibilities of planning his life. According to Rochester, life is a dangerous journey:

no sooner have you got settled in a pleasant resting-place, than a voice calls out to you to rise and move on, for the hour of repose is expired [10.237].

Such metaphors are the result of negative life experiences.

The speech of St. John Rivers is not so rich in metaphors, they mainly consist of an exposition of the stages of an aimless life and the difficulties that a person can face. The metaphors that John refers to have the conceptual content of "Life is an aimless journey", but they, unlike the metaphors of Rochester, indicate that the speaker, being aware of the existing obstacles, has not lost hope of overcoming them.

Experts note that narrative presentation has three types, including stability, development, and regression [11. 99-119]. Events that occur in a stable presentation are interconnected so much that the goal or result remains unchanged. The developing presentation reflects an optimistic view of life. It is clear that the declining presentation indicates the continuation of the depressive state and the lack of spiritual uplift. In this presentation, the main goal is to attract the attention of the listener, to awaken in him a sense of pity.

Regarding the classification of the above types of narrative, Jane's style of presentation is of the developing type, and Rochester's style of presentation is of the declining type. John's writing style has a stable expression. Indeed, in Jane's speech, there is a sense of faith in life, a willingness to share her successes with others and thereby win respect. Rochester's only desire is to awaken Jane's feelings of pity, so his attitude to life is expressed depressingly. Finally, John's speech reflects his faithfulness to religious obligations.

Based on the above, we can conclude that the studied literary work has a high frequency of using metaphors. The variety of metaphorical formations allows the author of the work to reveal the inner world of the characters more widely. In particular, the expansion of the semantic scope of the metaphorical expressions used by Jane is a product of the development of her cognitive abilities and capabilities based on the increase in life experience.

Metaphors allow the reader to get deeper into the thoughts of literary heroes, to understand the motives of their actions. In the course of analyzing the work of Sh. Bronte, we have come to the conclusion that the conceptual metaphor is undoubtedly important for the literary narrative, because with its help, the work can not only sparkle with bright colors, but also show the variety of artistic images created by the writer.

In particular, the analysis of the conceptual metaphor "Life is a Journey" showed that this metaphor with different content most clearly characterizes the life attitudes and moral principles of the characters of the work. Such an analysis can be continued on the basis of other works, as well as with the involvement of other metaphors. It would also be interesting later to conduct a comparative study of metaphors in the works of authors who are native speakers of different languages, which will allow us to identify the components of metaphors that are characteristic of a particular culture.

\section{References}

[1] Aristotel. Sochineniya. T. Ch. - M.: Misl, 1983. $-830 \mathrm{~s}$.

[2] Blek M. Metafora // Teoriya metafori. - M.: Progress, 1990. - S. 153 -172.

[3] Gyulumyans K.M. Obraznoye upotrebleniye nazvaniy jivotnix $\mathrm{v}$ sravneniyax i metaforax // Trudi SamGU. 
Vip.217. Voprosi frazeologii. IV. Samarkand, 1971. - S. 109-119.

[4] Nelyubin L.L. Tolkoviy perevodcheskiy slovar. - M.: Flinta, 2003. - 318s.

[5] Richards A.A. Filosofiya ritoriki // Teoriya metafori. - M. : Nauka, 1990. - S. 44-67.

[6] Mahmudov N., Odilov Yo. So'z ma'no taraqqiyotida ziddiyat. - T: Akadem nashr, 2014. - 288 b.

[7] Qobuljonova G. Metafora va uning tabiatiga qarashlar // O'zbek tili va adabiyoti, 2017. №2. - B. 40 - 46.

[8] Quronov D., Mamajonov Z., Sheraliyeva M. Adabiyotshunoslik terminlari. - T.: Akadem nashr, 2013. - 408 b.

[9] Allot N. Key terms in pragmatics. Beijing: Foreign Language Teaching and Research Press, 2010. - 289 p.

[10] Bronte Ch. Jane Eyre. - Cambridge: Cambridge University Press, 1996. - 530 p.

[11] Gergen K. J. Narrative, Moral Identity and Historical Consciousness: A Social
Construction Account / J. Straub // Narration, Identity and Historical Consciousness. Berghahn Books, 2005. - P. $99-119$. 
ASAR QAHRAMONLARINING DUNYOQARASHI VA METAFORALARNING MATNDA AKTUALLASHUVI

Ulugova Shohida Shoxruxovna

Samarqand Davlat chet tillar instituti, Samarqand, O'zbekiston

Ushbu maqolada badiiy asarlarda metaforalarning ishoatilish doirasi o'rganiladi. Xususan, Sh. Brontening "Jeyn Eyr" romani asosida insonning ruhiy holatini aks ettiruvchi konseptual metaforalar yordamida Jeyn, Rochester va Djon kabi asar bosh qahramonlari hayotining ichki dunyosi, dunyoqarashi va munosabatini ochib beradi, ularning xarakteridagi o'xshashlik va farqlarni ko'rsatadi.

Kalit so'zlar: konseptual metafora, mafkura, tushuncha, matn talqini.

\section{МИРОВОЗЗРЕНИЕ ГЕРОЕВ ПРОИЗВЕДЕНИЯ И АКТУАЛИЗАЦИЯ МЕТАФОР В ТЕКСТЕ \\ Улугова Шохида Шохруховна}

Самаркандский государственный институт иностранных языков, Самарканд, Узбекистан

В настоящей статье рассматривается употребление метафор в тексте художественных произведений. В частности, на материале романа Ш. Бронте “Джейн Эйр”, при помощи концептуальных метафор, отражающих психическое состояние человека, раскрывается внутренний мир, мировосприятие, мировоззрение и отношение к жизни главных персонажей произведения, таких как Джейн, Рочестер и Джон, показаны сходства и различия их характера.

Ключевые слова: концептуальная метафора, мировоззрение, концептуализация, интерпретащия текста 